\title{
Activity variations attending tungsten skarn formation, Pine Creek, California
}

\author{
Philip E. Brown ${ }^{1}$ and Eric J. Essene ${ }^{2}$ \\ ${ }^{1}$ Department of Geology and Geophysics, University of Wisconsin, 1215 W. Dayton St., Madison, WI 53706 USA \\ ${ }^{2}$ Department of Geological Sciences, The University of Michigan, Ann Arbor, MI 48109-1063 USA
}

\begin{abstract}
An integrated geochemical analysis of the wellexposed Pine Creek, California tungsten skarn deposit has been undertaken to evaluate changes in chemical gradients across various lithologies. Thermodynamic calculations using available experimental and thermodynamic data allow limits to be assigned to the activities of important chemical components in the metasomatic environment. Quantifiable changes in "non-volatile" component activites $(\mathrm{CaO}, \mathrm{MgO}$, $\left.\mathrm{Al}_{2} \mathrm{O}_{3}, \mathrm{Fe}_{2} \mathrm{O}_{3}, \mathrm{WO}_{3}\right)$ and in fugacities $\left(\mathrm{O}_{2}, \mathrm{~F}_{2}\right)$ have been traced across the system. The activities of $\mathrm{Al}_{2} \mathrm{O}_{3}, \mathrm{Fe}_{2} \mathrm{O}_{3}$ and $\mathrm{WO}_{3}$ generally increase from the marble $\left(<10^{-2}\right.$, $<10^{-6},<10^{-5}$ respectively), through the outer skarn zone and into the massive garnet skarn $\left(10^{-1.7 \pm 0.3}, 10^{-3.4 \pm 0.4}\right.$, $10^{-4.8 \pm 0.1}$ ) while $\mathrm{CaO}$ and $\mathrm{MgO}$ activities decrease for the same traverse from $10^{-5}$ and $10^{-2.1 \pm 1}$ respectively, to $<10^{-5.7}$ and $<10^{-3}$. Calculated oxygen fugacities are $10^{-23.5+1.0}$ at $T=800 \mathrm{~K}\left(527^{\circ} \mathrm{C}\right)$, about one $\log$ unit below $\mathrm{QFM}$, and more reducing than that required by $\mathrm{Mt}-\mathrm{Py}-$ Po. The high variance of the garnet-pyroxene-quartz assemblages adds sufficient uncertainty to the calculated activities for individual specimens that only the large-scale trends survive the small-scale scatter. None of the chemical variables emerge as major independent or controlling factors for the mineralogy or phase compositions. Changes in the activity of one component may be offset by compensatory changes in another resulting in an environment that, while different from Pine Creek, could still host scheelite mineralization. Mass balance calculations indicate that the exposed endoskarn cannot have supplied the necessary chemical components to convert the country rock to skarn.
\end{abstract}

\section{Introduction}

Contact skarns form in open (non-isochemical) environments and hence a full understanding of their formation requires consideration of actual quantities of both non-volatile and volatile components added or subtracted from the skarn as well as the activities of these components. This paper derives such information for the Pine Creek, California tungsten skarn and follows the mass transfers attending skarn formation in this moderate depth, roof pendant setting.

Igneous petrologists (e.g. Carmichael et al. 1974) have used quantitative plots showing the activity of silica vs. activity of alkalis and activity of silica vs. temperature to quantify relationships in a melt or to classify igneous rocks.

Offprint requests to: $\mathrm{P}$. E. Brown
Calculations of activities of various components in metamorphic and metasomatic environments have been applied only rarely (e.g. Bohlen and Essene 1978; Bowman and Essene 1984), although Burt (1971 a, b, 1972a, b) has calculated many schematic topologies for the minerals and components found in skarn-forming environments. Generally, however, his calculated figures provide only a qualitative understanding of the nature of these variables in metamorphic and metasomatic environments. Recent thermochemical data (Robie et al. 1978; Helgeson et al. 1978) allow calculation of numerical values for the axes of these activity/ temperature/fugacity plots at specified pressures.

Bohlen and Essene (1978) used a $f \mathrm{O}_{2}-f \mathrm{~F}_{2}$ diagram to deduce upper and lower limits for fluorine, oxygen, hydrogen and water fugacities in fluorite-bearing granulite facies rocks from the central Adirondacks. Bowman (1978) and Bowman and Essene (1984) describe in detail the chemical parameters attending formation of the unmineralized, silica-undersaturated skarns around a satellite intrusion of the Boulder Batholith near Elkhorn, Montana. They show the importance of considering silica and alumina activities as well as $f \mathrm{O}_{2}, a \mathrm{CO}_{2}, P, T$, etc. and suggest, without quantification, that $a \mathrm{Fe}_{2} \mathrm{O}_{3}$ may be an important variable in cotrolling mineralogical and compositional changes in the skarn.

Embellishing on the framework established by these earlier workers, this paper presents calculations of activities relating to the formation of the Pine Creek, California tungsten skarn in the Sierra Nevada Mountains.

\section{Geology and $P-T-X(f)$ framework}

The Pine Creek, California tungsten mine is the largest deposit and only operating property in the Bishop District (Bateman 1965). The scheelite- and molybdenite-bearing skarns are developed at contacts between the mineralizing Morgan Creek Quartz Monzonite (MCQM) (Newberry 1982) and Upper Paleozoic carbonate rocks present as roof pendants and septa in both the Tungsten Hills and the more extensive Pine Creek Pendant (Fig. 1).

Silicate phase relations in the contact aureole of the MCQM limit pressures to less than 2 kbars (Brown 1980; Brown et al. 1985), and 1.5 kbars has been chosen as a working value for our thermodynamic calculations. Temperatures are constrained by calcite-dolomite thermometry and calc-silicate phase relations to $500-600^{\circ} \mathrm{C}$ (Brown $1980)$, and $527^{\circ} \mathrm{C}(800 \mathrm{~K})$ is used for ease of calculation in the following discussion. An assumption of isothermal 


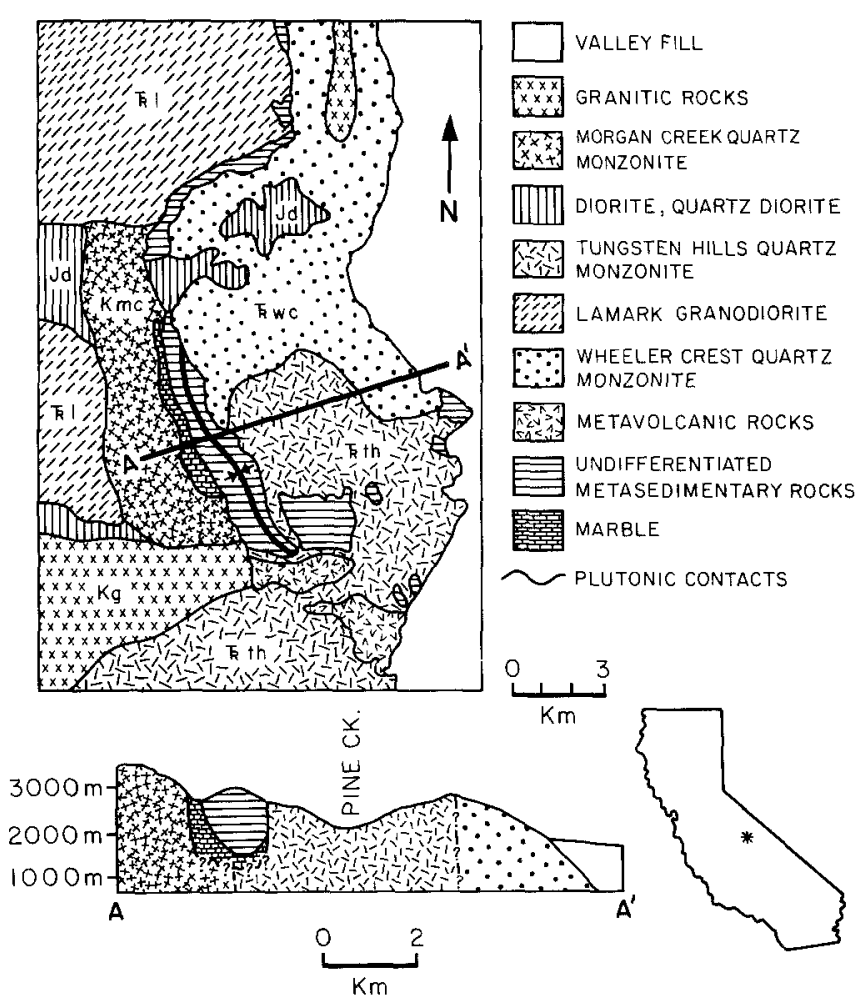

Fig. 1. Simplified geologic map and cross section showing the spatial relationship of the Pine Creek septum to the surrounding intrusive rocks. The schematic WSW-ENE cross section A-A' indicates the synclinal structure of the metasedimentary rocks. The nature of the septum below 2,000 $\mathrm{m}$ is speculative. Geology modified from Bateman (1965) and Newberry (1982)

conditions for the prograde, main-stage skarn forming event only approximates the actual time/temperature development of the skarn. The thermodynamically underdetermined nature of the skarn precludes exact specification of time/temperature relations. The purity of the marble leads to a paucity of univariant or invariant assemblages and to an inability to tightly constrain $\mathrm{X}\left(\mathrm{CO}_{2}\right)$. Available data show that $\mathrm{X}\left(\mathrm{CO}_{2}\right)$ decreases rapidly toward the MCQM and most of the skarn formation took place with $\mathrm{X}\left(\mathrm{CO}_{2}\right)$ $<0.1$ (Brown et al. 1985). The generally restricted lateral extent of the skarn $(<10-20 \mathrm{~m})$ is supportive of the isothermal assumption. Extending this analysis to conditions of retrograde skarn alteration or even the final sulfidation steps of the main-stage skarn formation would require either better temperature control, perhaps using fluid inclusion filling temperatures, or changes in the above assumptions.

Calculations of gas species for the system $\mathrm{C}-\mathrm{O}-\mathrm{H}-$ $\mathrm{S}-\mathrm{F}$ for early- and main-stage skarn formation demonstrate that water and carbon dioxide comprise $>94 \%$ of the fluid phase, the remainder being mainly $\mathrm{H}_{2} \mathrm{~S}$ (Brown 1980; Brown et al. 1985). The absence of primary iron and titanium oxides in the skarn presents a problem for determining oxygen fugacities. Consideration of other minor gases (notably $\mathrm{F}_{2}$ ) in rocks of appropriate bulk composition limits oxygen fugacities to $10^{-23.5 \pm 1}$. While this approach gives fairly good limits on $f \mathrm{O}_{2}$, more precise determinations are necessary to decide whether or not $f \mathrm{O}_{2}$ variations were important in determining skarn mineralogy and phase composition. Calculations deriving tighter limits on $\mathrm{fO}_{2}$ variations as well as the importance and range of non-volatile component activities will be discussed in this paper. It is interesting to note that while loosely referred to here as "non-volatile", the components are easily transported in the skarn-forming fluids and their activities generally lie in the range $10^{-1}$ to $10^{-10}$, overlapping the average $a \mathrm{~S}_{2}$ for this $P-T$ regime.

Whereas the calculations presented below were made for conditions at $1.5 \mathrm{kbars}$ and $800 \mathrm{~K}$, the methodology applies generally to skarns forming in other $P-T$ regimes. Large pressure variations will have small but often significant effects on the position of calculated equilibria because most of the reactions considered have small volume changes. Temperature variations will have pronounced effects on the location of equilibria but, in general, will be simply manifested by shifts in the topological grid with respect to the axes of the activity/fugacity plots.

\section{Activity calculations}

Standard thermodynamic calculations, using Eq. (1), for reactions among minerals and simple oxides, yield activities of non-volatile components and constraints on the stabilities of skarn minerals. Specifically, at equilibrium:

$0=\Delta G_{r}^{P, T}=\Delta G_{r, s}^{1 \mathrm{bar}, 800 \mathrm{~K}}+\Delta P \Delta V_{r, s}+R T \ln (K)$

where

$\Delta G_{r, s}^{1 \text { bar, } 800 \mathrm{~K}}=\Sigma G_{f, \text { prod }}^{800 \mathrm{~K}}-\Sigma G_{f, \text { reac }}^{800 \mathrm{~K}}$ for the solids,

$\Delta V_{r, s}=\Sigma V_{\text {prod }}-\Sigma V_{\text {reac }} \quad$ for the solids,

$\triangle P=1,499$ bars,

$R=8.3143(\mathrm{~J} / \mathrm{mol} \mathrm{K})$,

$T=800 \mathrm{~K}$

and $K=$ equilibrium constant involving any volatile phases and any phases with other than unit activities. As a simple example, the following calculation specifies one of the stability limits for wollastonite with respect to quartz for variable $a \mathrm{CaO}$.

$\mathrm{CaSiO}_{3}=\mathrm{SiO}_{2}+\mathrm{CaO}$

Wollastonite $=$ Quart $z+$ Lime,

$\triangle V=2.269-3.993=-1.724 \mathrm{~J} / \mathrm{bar} \quad \triangle P \Delta V=-2,584 \mathrm{~J}$,

$0=-765,323-551,447+1,406,860-2,584+R T \ln a \mathrm{CaO}$,

$\log a \mathrm{CaO}=-5.73$.

This simple reaction limits the activity of $\mathrm{CaO}$ in the skarns where quartz is present and wollastonite generally is not. Similar calculations, as summarized in the following figures, delimit the activities of $\mathrm{CaO}, \mathrm{Al}_{2} \mathrm{O}_{3}, \mathrm{Fe}_{2} \mathrm{O}_{3}, \mathrm{MgO}$ and $\mathrm{WO}_{3}$ as well as the fugacity of oxygen. The data base for these calculations is given in Table 1. Several free energies not available in the literature have been derived from experimental data. Specificaliy, experimental data (Gustafson 1974; Liou 1974; Gamble 1982; Burton et al. 1982) permit calculation of high temperature $A G$ 's for andradite and hedenbergite which agree well with free energies determined by Taylor and Liou (1978) and by Navrotsky and Coons (1976), respectively, from other experimental work.

Lyon and Westrum (1968) present low-temperature heat capacity data for scheelite between 4 and $350 \mathrm{~K}$ while Yakovleva and Rezukhina (1960) report high-temperature heat capacity data from $600-1,100 \mathrm{~K}$. Equation (3) was fitted to a smooth curve joining these data and integrated to obtain high-temperature entropies and enthalpies from $298-600 \mathrm{~K}$, i.e.:

$$
\begin{aligned}
& C p=a+b T-c T^{-2} \\
& S_{600}^{0}-S_{298}^{0}=\int_{298}^{600} \frac{\left(31.062+0.005215 T-474893.6 T^{-2}\right) d T}{T} \\
& H_{600}^{0}-H_{298}^{0}=\int_{298}^{600} C p d T .
\end{aligned}
$$


Table 1. Thermodynamic Data and Mineral Abbreviations

\begin{tabular}{lllrlr}
\hline Phase & Formula & Abbrev. & \multicolumn{1}{c}{$\Delta G_{800}^{0}$} & Ref. & $V_{298}^{0}$ \\
\hline Akermanite & $\mathrm{Ca}_{2} \mathrm{MgSi}_{2} \mathrm{O}_{7}$ & $\mathrm{Ak}$ & $-3,349.260$ & {$[1]$} & 9.28 \\
Andradite & $\mathrm{Ca}_{3} \mathrm{Fe}_{2} \mathrm{Si}_{3} \mathrm{O}_{12}$ & $\mathrm{And}$ & $-4,878.603$ & {$[4]$} & 13.16 \\
Anorthite & $\mathrm{CaAl}_{2} \mathrm{Si}_{2} \mathrm{O}_{8}$ & $\mathrm{An}$ & $-3,626.807$ & {$[2]$} & 10.08 \\
Calcite & $\mathrm{CaCO}_{3}$ & $\mathrm{Cc}$ & $-1,001.753$ & {$[2]$} & 3.69 \\
Corundum & $\mathrm{Al}_{2} \mathrm{O}_{3}$ & $\mathrm{Cor}$ & $-1,424.886$ & {$[2]$} & 2.56 \\
Diopside & $\mathrm{CaMgSi}_{2} \mathrm{O}_{6}$ & $\mathrm{Di}$ & $-2,735.660$ & {$[3]$} & 6.61 \\
Dolomite & $\left.\mathrm{CaMg}_{2} \mathrm{CO}_{3}\right)_{2}$ & $\mathrm{Dol}$ & $-1,892.522$ & {$[1]$} & 6.43 \\
Fayalite & $\mathrm{Fe}_{2} \mathrm{SiO}_{4}$ & $\mathrm{Fa}$ & $-1,217.398$ & {$[2]$} & 4.64 \\
Fluorite & $\mathrm{CaF}_{2}$ & $\mathrm{Fl}$ & $-1,092.768$ & {$[1]$} & 2.45 \\
Grossular & $\mathrm{Ca}_{3} \mathrm{Al}_{2} \mathrm{Si}_{3} \mathrm{O}_{12}$ & $\mathrm{Gr}$ & $-5,672.427$ & {$[2]$} & 12.53 \\
Hedenbergite & $\mathrm{CaFeSi}_{2} \mathrm{O}_{6}$ & $\mathrm{Hd}$ & $-2,414.716$ & {$[4]$} & 6.79 \\
Hematite & $\mathrm{Fe}_{2} \mathrm{O}_{3}$ & $\mathrm{H}$ & -613.218 & {$[2]$} & 3.03 \\
Lime & $\mathrm{CaO}$ & $\mathrm{CaO}$ & -551.447 & {$[2]$} & 1.68 \\
Magnetite & $\mathrm{Fe}_{3} \mathrm{O}_{4}$ & $\mathrm{M}$ & -850.258 & {$[2]$} & 4.45 \\
Periclase & $\mathrm{MgO}$ & $\mathrm{MgO}$ & -514.903 & {$[2]$} & 1.12 \\
Perovskite & $\mathrm{CaTiO}_{3}$ & $\mathrm{Pv}$ & $-1,435.573$ & {$[1]$} & 3.36 \\
Quartz & $\mathrm{SiO}_{2}$ & $\mathrm{Q}$ & -765.323 & {$[2]$} & 2.27 \\
Rutile & $\mathrm{TiO}_{2}$ & $\mathrm{Ru}$ & -797.643 & {$[1]$} & 1.88 \\
Scheelite & $\mathrm{CaWO}$ & $\mathrm{Sch}$ & $-1,359.051$ & {$[5]$} & 4.70 \\
Sphene & $\mathrm{CaTiSiO}_{5}$ & $\mathrm{Sph}$ & $-2,224.454$ & {$[1]$} & 5.56 \\
Tungsten & $\mathrm{WO}_{3}$ & WO & -634.989 & {$[1]$} & 3.16 \\
Trioxide & & & & & \\
Wollastonite & $\mathrm{CaSiO}_{3}$ & Wo & $-1,406.860$ & {$[2]$} & 3.99 \\
\hline
\end{tabular}

$\Delta G^{\circ}$ is given in $\mathrm{KJ} /$ mole; $V^{\circ}$ has units of $\mathrm{J} / \mathrm{bar}$; Temperature $800 \mathrm{~K}$.

References: 1. Robie et al. (1978); 2. Robinson et al. (1983); 3 Charlu et al. (1978); 4. calculated from Liou (1974), Gustafson (1974), Burton et al. (1982), Gamble (1982); 5. calculated this study

Above $600 \mathrm{~K}$, Yakovleva and Rezukhina's equation:

$C p=26.48+0.010945(T)$

was used; combining these equations permits high-temperature free energies for scheelite to be calculated which in turn allows $a \mathrm{WO}_{3}$ to be calculated for reactions such as:

$\mathrm{CaSiO}_{3}+\mathrm{WO}_{3}=\mathrm{CaWO}_{4}+\mathrm{SiO}_{2}$.

Wollastonite $+\mathrm{WO}_{3}=$ Scheelite + Quartz

\section{Reduced activity calculations}

To apply calculated activity diagrams to natural assemblages, the activities of component oxides must be adjusted for the effects of solid solutions. The only phases for which these reduced activity calculations have been carried out are the garnets and pyroxenes; the rest of the minerals are either essentially end-member in composition (quartz, wollastonite, calcite, fluorite, rutile) or there are insufficient thermochemical data (known to us) available even to compute their end-member equilibria (vesuvianite, epidote). Scheelite, with variable contents of $\mathrm{CaMoO}_{4}$ solid solution $(0-20 \%$, Wright 1973), is treated as a pure phase for the one diagram involving $a \mathrm{WO}_{3}$. Sphene contains up to $20 \% \mathrm{Al}$ substitution for Ti in the Pine Creek skarns and marbles (Brown 1980) but this has been ignored as a simplifying step in these calculations.

To rigorously calculate the reduced activities, a knowledge of composition/activity relationships for the phases involved is necessary. Experimental data are usually needed to calculate the directions and magnitudes of the deviations from ideality. One or two parameter (Margules) type models are necessary to adequately describe the mineral solutions. These parameters are normally a function of temperature, pressure and composition; they therefore have no great predictive power and cannot be applied outside the range of conditions for which they were derived.

Activity coefficients have been derived, in a variety of forms, for ranges of binary and ternary garnet solid solutions (Saxena 1973; Ganguly and Kennedy 1974; Hensen et al. 1975; Ganguly 1976; Newton et al. 1977; Cressey et al. 1978). These determinations have shown that both positive and negative deviations from ideality occur and simple $a=\mathrm{X}$ relationships generally do not suffice for these minerals. Garnets related to main-stage tungsten mineralization can be adequately described as grossular-andradite solutions (Brown 1980; Newberry 1982, 1983). Ganguly (1976) calculated an interaction parameter $(W=-6.43 \mathrm{KJ} / \mathrm{mole}$ ) for this solid solution but concluded that due to other uncertainties, an assumption of ideal mixing is reasonable. Bird and Helgeson (1980) similarly conclude that within the uncertainty of available data, mixing of aluminum and iron on the octahedral sites in garnets is ideal. Huckenholz et al. (1981) suggest that this solid solution is not ideal due to excess molar volumes of intermediate compositions. Because definitive data are lacking for the solid solutions present in the Pine Creek garnets, the diluents in the garnets have been modeled using an ideal ionic model (Ganguly 1976; Bird and Helgeson 1980). Other uncertainties in the present calculations likely exceed the possible errors generated by this simplifying assumption. Specifically, the activity $(a)$ has been calculated by the relationship:

$a_{\mathrm{And}}^{\mathrm{Gar}}=\left(\mathrm{X}_{\mathrm{Fe}^{+3}}\right)^{2}$.

In general, the substitutions in the octahedral sites are more extensive and variable than those in the calcium sites. While manganese is the most important diluent for calcium, it is present in fairly constant amounts and has been ignored in the following calculations as has the minor ferrous iron inferred in the garnets from charge balance considerations. Omitting these diluents from consideration reduces the rigorous ionic model:

$a_{\mathrm{And}}^{\mathrm{Gar}}=\left(\mathrm{X}_{\mathrm{Ca}}\right)^{3}\left(\mathrm{X}_{\mathrm{Fe}}+3\right)^{2}$

to the simplified form used here. Errors imparted by these omissions are probably no greater than those generated by the assumptions that the activity coefficient is equal to one and that isothermal conditions obtained.

For the skarn pyroxene solid solutions, Saxena (1976) states that in the absence of any other information on the behavior of iron and magnesium in the M1 site of clinopyroxene, the simplest approximation of ideal solution for the site is appropriate. Froese and Gordon (1974) derive activity coefficients for coexisting granulite facies pyroxenes from Australia. Their Fig. 1 shows a maximum deviation of 0.04 mole fraction for an ideal solution model versus a simple-mixture solution model. Based on these two studies and the uncertainties outlined above for the present calculations, a simple ionic model approach was used:

$a_{\mathrm{d}}^{\mathrm{Cpx}}=\left(\mathrm{X}_{\mathrm{Fe}}^{\mathrm{M} 1}\right)\left(\mathrm{X}_{\mathrm{Ca}}^{\mathrm{M} 2}\right)$.

There is essentially no substitution for calcium in the Pine Creek pyroxenes and negligible substitution of Tschermak's molecule because the skarn is quartz-saturated. Until experimentally derived activity coefficients are available, this simplified calculation will be the basis for modeling the effects of the diluents.

\section{Non-volatile component activities}

A compilation of several hundred microprobe analyses of garnets and pyroxenes from the Pine Creek skarn is presented as Fig. 2. Each data point represents a single specimen with the vertical and horizontal bars indicating the complete range of garnet and pyroxene analyses for that sample. Individual bars represents between 2 and 40 separate analyses with the average number being about ten. Core and rim compositions have not been differentiated in compiling these data nor has the compilation been weighted for such effects as a single divergent analysis greatly increasing the apparent spread of compositions for an otherwise tight cluster. Correcting for these effects causes a decrease in the individual ranges and leads to a lessened 


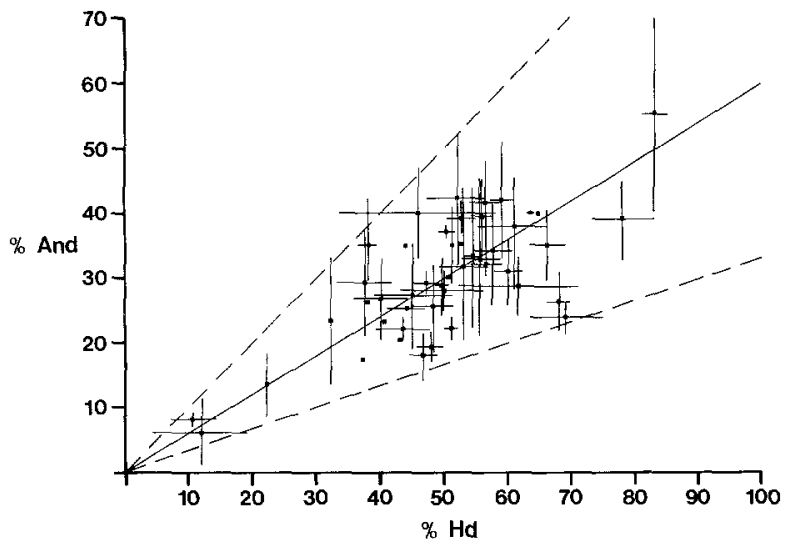

Fig. 2. Electron microprobe analyses for garnets and pyroxenes from the outer- and inner-skarn units. Each dot represents a single thin section with the total range of compositions represented by the vertical and horizontal bars. The solid and dashed lines represent the average trend and spread of analyses respectively

spread about the means plotted as the points in Fig. 2. For the purpose of choosing an average skarn value however, the total range of analyses has been used. As derived below, lines of constant $f \mathrm{O}_{2}$ can be superimposed on this compilation and thus a unique $f \mathrm{O}_{2}$ determined for any garnet/pyroxene pair in the skarn. This result follows most closely from a discussion of one of the following activity plots and will therefore be examined in turn.

The data in Fig. 2 suggest that an average garnet composition of $30 \%$ andradite and an average pyroxene of $50 \%$ hedenbergite are representative of the massive garnet skarn. For each of the figures that follows, this average mineral pair has been used to locate the appropriate exchange equilibria curve on the activity plots. The spread about this average is that shown by the range of values plotted in Fig. 2. For the light-colored outer skarn zone, garnets will initially be assumed to be pure grossular. Pyroxenes in this outer skarn and in the country rock marble are modeled as pure diopside.
Many possible choices of chemical components are possible to describe skarn forming reactions (Burt 1972a, 1978; Bowman and Essene 1984). For example, Burt (1972a) chose the fictive component $\mathrm{F}_{2} \mathrm{O}_{-1}$ to schematically indicate relationships among sanidinite facies skarn minerals. Information about the chemical potential of water would allow $\mu \mathrm{F}_{2} \mathrm{O}_{-1}$ to be expressed in terms of $\mu \mathrm{HF}$. In addition, $\mu \mathrm{F}_{2}$ or $f \mathrm{~F}_{2}$ are equally valid choices, For the present paper, $f \mathrm{O}_{2}, f \mathrm{~F}_{2}, a \mathrm{Al}_{2} \mathrm{O}_{3}, a \mathrm{CaO}, a \mathrm{Fe}_{2} \mathrm{O}_{3}, a \mathrm{MgO}$ and $a \mathrm{WO}_{3}$ have been chosen for convenience of calculation as thermodynamic data are readily available for these species. Without specific knowledge of speciation and complexing of these elements in the actual skarn fluid, no one choice of components is any more correct than another.

\section{$\mathrm{CaO}$ activities}

Figure 3 is a plot of $\log a \mathrm{CaO}$ vs $\log f \mathrm{O}_{2}$. The solid reactants and products for each reaction are given with the abbreviations summarized in Table 1 . The stability of fluorite is delimited, for variable fluorine fugacities, by the boundaries angling down from the upper right on this figure. The importance of fluorite stability on this figure is open to question because Newberry (1982) presents evidence that the fluorite at Pine Creek is related to the retrograde "hydrosilicate" skarn stage. This stage follows the main-stage skarn growth and occurs at a lower temperature $\left(400^{\circ} \mathrm{C}\right.$ ). Contrary to this conclusion of Newberry (1982), several of the samples examined in the course of this study contain significant amounts of fluorite that appears to be part of the main-stage outer skarn growth. The fact that fluorite is a common accessory mineral in the outer skarn zone at Pine Creek but is generally absent in the main garnet skarn may also support its high temperature, early origin. Conversely, Newberry would argue that fluorite is present only in the altered outer skarn because it was in this zone that high calcium activities were generated in the retrograde fluids by the breakdown of wollastonite, In any case, the fluorite contours on Fig. 3 may be considered informational and do not weigh heavily in the conclusions that follow.

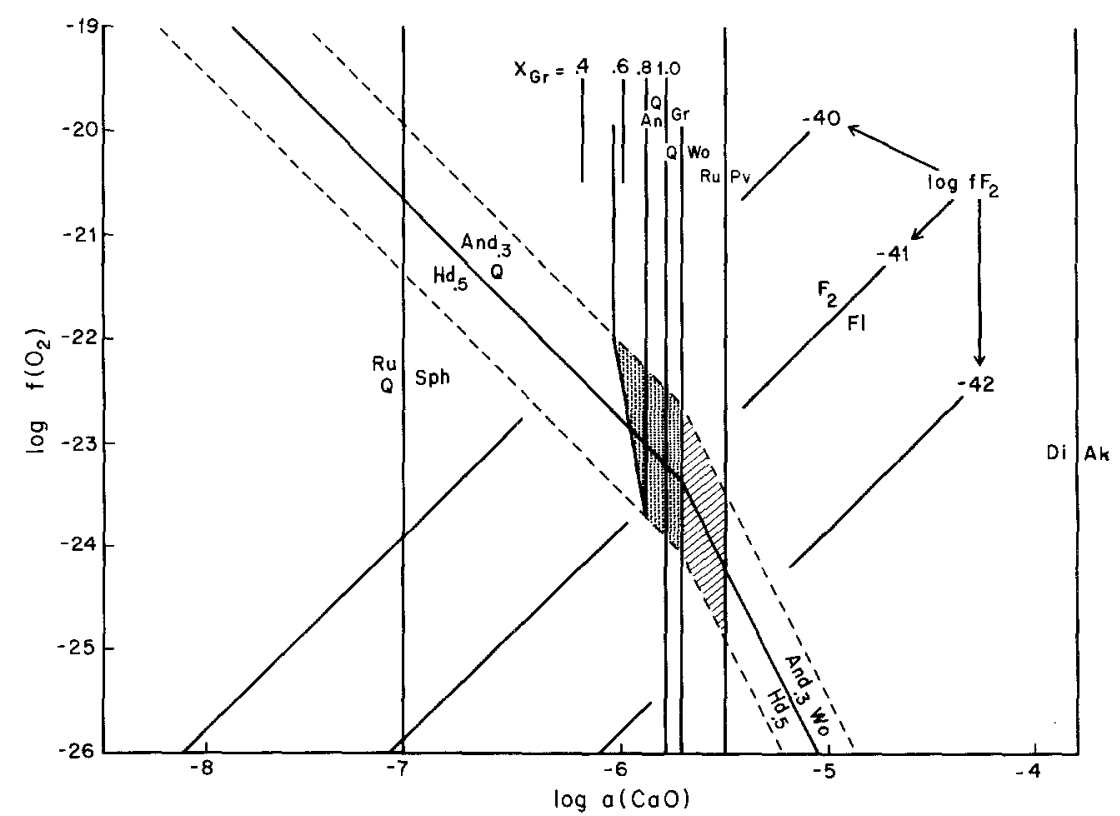

Fig. 3. Calculated $f\left(\mathrm{O}_{2}\right)-a(\mathrm{CaO})$ diagram for $T=800 \mathrm{~K}, P=1.5$ kbars. The ruled area is consistent with mineralogy exhibited by the iron-poor outer skarn zone. The stippled area represents conditions for the massive garnet-pyroxene skarn. See the text for a discussion of the inclined garnet-quartzpyroxene boundaries 
Consideration of the average skarn composition discussed above, $30 \%$ andradite in the garnet and $50 \%$ hedenbergite in the pyroxene, allows the position of reaction:

$2 \mathrm{CaFeSi}_{2} \mathrm{O}_{6}+\mathrm{CaO}+1 / 20_{2}=\mathrm{Ca}_{3} \mathrm{Fe}_{2} \mathrm{Si}_{3} \mathrm{O}_{12}+\mathrm{SiO}_{2}$

Hedenbergite + Lime $+1 / 20_{2}=$ Andradite + Quartz

to be calculated. The dashed lines outline the range of values generated by considering the spread of analyses shown in Fig. 2.

The ruled areas cover the range of $a \mathrm{CaO}-\mathrm{fO}_{2}$ conditions consistent with the mineralogical and compositional data. For the marble, it is only possible to put very wide limits on the $\mathrm{CaO}$ activity. The presence of diopside and the stability of sphene limit $a \mathrm{CaO}$ to between $10^{-3.8}$ and $10^{-7.1}$ for these $P-T$ conditions. Because the trend across the outer skarn and inner garnet skarn corresponds to a decrease in $\mathrm{CaO}$ activity, the most likely value for the marble is in the upper half of the range, probably above $10^{-5.7}$.

The outer light-colored skarn zone is typified by the presence of wollastonite, vesuvianite, (fluorite?) and generally quartz (in addition to calcite + diopside + / - sphene) although silica activities less than one may locally persist (as in the marble). The ruled area for this zone has been chosen to include $\mathrm{CaO}$ activities greater than $10^{-5.7}$ (reaction 2) and arbitrarily less than that given by the reaction:

$\mathrm{TiO}_{2}+\mathrm{CaO}=\mathrm{CaTiO}_{3}$.

Rutile + Lime $=$ Perovskite.

This latter reaction requires silica activities less than one which may occur as shown by scattered occurrences of rutile. The upper and lower $\mathrm{fO}_{2}$ boundaries are not constrained by the phase assemblages since no readily reducible or oxidizable species are present as, in general, iron had not yet been added to the rocks from the metasomatic fluid. The presence of main-stage fluorite would limit fluorine fugacities to $10^{-41.5 \pm 5}$ for reasonable $f \mathrm{O}_{2}$ 's in the range $10^{-23.5 \pm 1.0}$. The lack of thermochemical data for vesuvianite precludes its use in further limiting $f \mathrm{O}_{2}$ or $a \mathrm{CaO}$ at the present time.

Within the final few centimeters of the outer skarn zone adjacent to the massive skarn, grossular-rich garnet begins to dominate the calc-silicate assemblage. The visually very sharp contact between the outer and inner skarns marks a color discontinuity which reflects a compositional discontinuity as hedenbergite and andradite become important components in the pyroxenes and garnets, respectively. Within the first few centimeters of the massive skarn, fluorite, wollastonite and vesuvianite generally are no longer present except where rarely included in garnet. These mineralogical changes may be explained by a lowered activity of $\mathrm{CaO}$ (Fig. 3). An $a \mathrm{CaO}$ decreased below $10^{-5.7}$, permits quartz to be stable instead of wollastonite. Assuming $f \mathrm{~F}_{2}$ remained the same or decreased, fluorite would become unstable as $a \mathrm{CaO}$ decreased. The lower limit on $a \mathrm{CaO}$ can be derived from the lack of plagioclase in the skarn. The reaction:

$\mathrm{CaAl}_{2} \mathrm{Si}_{2} \mathrm{O}_{8}+\mathrm{SiO}_{2}+2 \mathrm{CaO}=\mathrm{Ca}_{3} \mathrm{Al}_{2} \mathrm{Si}_{3} \mathrm{O}_{12}$

Anorthite + Quartz + Lime $=$ Grossular

limits the $a \mathrm{CaO}$ when modeled for impurities (Fig. 3). Thus the boundaries of the stippled field representing conditions in the garnet skarn are given by the lower stability of garnet and the upper stability of quartz; the $\mathrm{O}_{2}$ limits are supplied by reaction (11).

Compositional and mineralogical information thus tightly constrain the gradients in $\mathrm{CaO}$ activities across the Pine Creek metasomatic zone assuming isothermal conditions. $\mathrm{CaO}$ activities were highest in the marble $\left(10^{-5.5}\right)$, decreased slightly in the outer skarn zone $\left(10^{-5.7}\right.$ to $\left.10^{-5.5}\right)$ and decreased still further in the massive skarn $\left(10^{-5.9 \pm 0.2}\right)$. Fluorine fugacities increased from below $10^{-42}$ in the marble to a maximum of about $10^{-4 \cdot 1.5}$ in the outer skarn. The decrease in $a \mathrm{CaO}$ in the garnet skarn coupled with either constant or falling $f \mathrm{~F}_{2}$ may account for the lack of fluorite in the main garnet skarn. Oxygen fugacities are not tightly constrained in the outer skarn zone but appear to increase slightly and range from $10^{-22}$ to $10^{-24}$ for the massive garnet skarn.

\section{$\mathrm{AI}_{2} \mathrm{O}_{3}$ and $\mathrm{MgO}$ activities}

Figure 4 presents the results of calculations for $\mathrm{MgO}$ and $\mathrm{Al}_{2} \mathrm{O}_{3}$ activities. This figure also shows graphically that given garnet/pyroxene pairs are associated with unique $\mathrm{fO}_{2}$ 's and allows Fig. 2 to be contoured. The results are given in Fig. 5 and will be discussed below. This figure was constructed as described above for the $a \mathrm{CaO}$ plot with appropriate reductions in activities.

No lower limit of $a \mathrm{Al}_{2} \mathrm{O}_{3}$ can be placed for the marble because there are no phases present that allow such a boundary to be calculated. The activity of $\mathrm{Al}_{2} \mathrm{O}_{3}$ is certainly less than $10^{-1.7}$ which is the value at the boundary between wollastonite and grossular, $\mathrm{MgO}$ activities are somewhat more tightly constrained. For most of the marble, the $a \mathrm{MgO}$ must lie above the breakdown of diopside $\left(10^{-3.1}\right)$ and below the stability of dolomite $\left(10^{-1.2}\right)$. The reaction:

$\mathrm{CaMg}\left(\mathrm{CO}_{3}\right)_{2}=\mathrm{CaCO}_{3}+\mathrm{MgO}+\mathrm{CO}_{2}$

Dolomite $=$ Calcite + Periclase $+\mathrm{CO}_{2}$

has been located for $\mathrm{X}\left(\mathrm{CO}_{2}\right)=0.2$, a value consistent with the maximum $\mathrm{X}\left(\mathrm{CO}_{2}\right)$ in the skarns (Brown 1980; Brown et al. 1985). In a number of samples from one of the smaller mines in the Pine Creek pendant, the Hanging Valley Mine, primary periclase requires much higher $\mathrm{MgO}$ activities $(a=$ 1). The arrow in Fig. 4 has been drawn schematically showing a decrease in $a \mathrm{MgO}$ and an increase in $a \mathrm{Al}_{2} \mathrm{O}_{3}$ as the outer skarn zone is encountered.

The presence of quite pure diopside with wollastonite and quartz in the outer skarn zone defines a unique $a \mathrm{MgO}=10^{-3,2}$. Again the $a \mathrm{Al}_{2} \mathrm{O}_{3}$ is less well defined, simply being less than $10^{-1.7}$ (ruled area). The presence of grossular-rich garnet with wollastonite defines a unique area on this diagram around $a \mathrm{MgO}=10^{-3.2}$ and $a \mathrm{Al}_{2} \mathrm{O}_{3}=$ $10^{-1.7}$. Again, thermodynamic data for vesurianite would undoubtedly help to place limits on the activities of these two components in this skarn zone.

The stippled area centered upon $a \mathrm{MgO}=10^{-3.25}$ and $a \mathrm{Al}_{2} \mathrm{O}_{3}=10^{-1.7}$ is bounded by the stability limits of $\operatorname{Gr}(0.7)$ and $\mathrm{Di}(0.5)$ and represents conditions in the garnet skarn. The reaction:

$\mathrm{Ca}_{3} \mathrm{Al}_{2} \mathrm{Si}_{3} \mathrm{O}_{12}+3 \mathrm{SiO}_{2}+3 \mathrm{MgO}=3 \mathrm{CaMgSi}_{2} \mathrm{O}_{6}+\mathrm{Al}_{2} \mathrm{O}_{3}$

Grossular + Quartz + Periclase $=$ Diopside + Corundum 


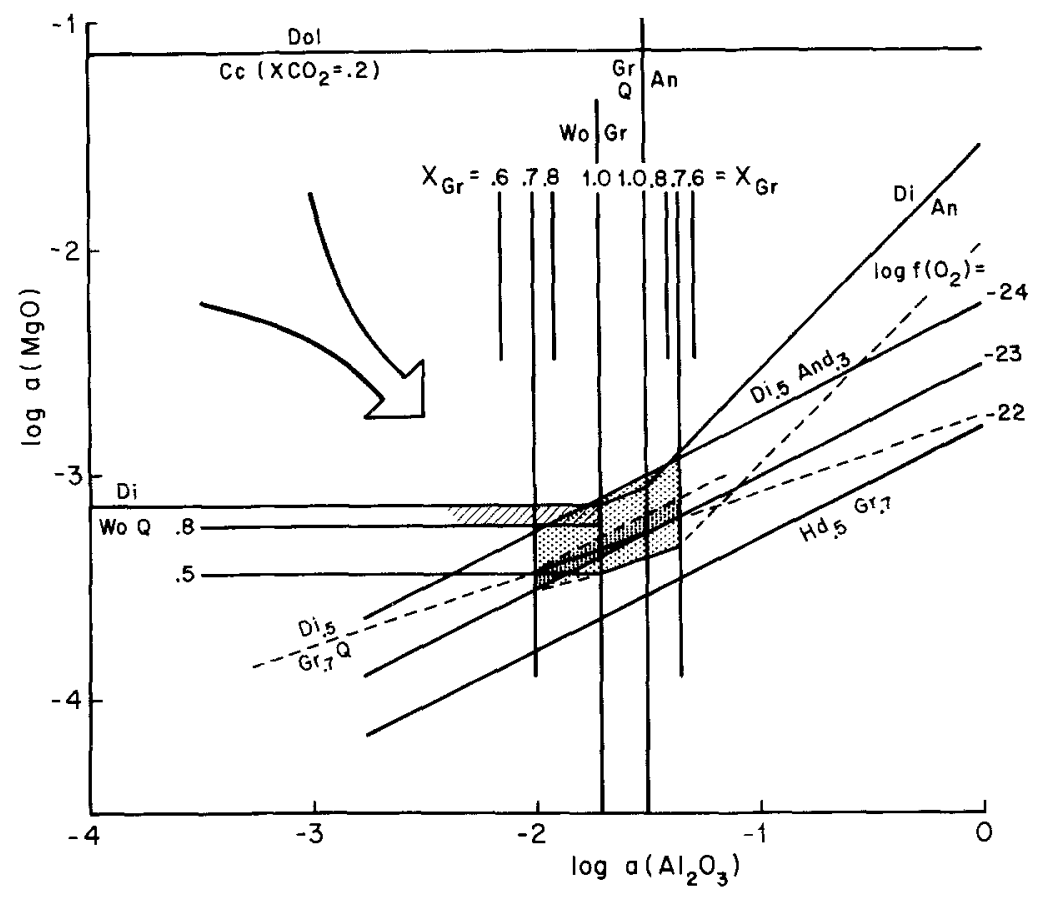

Fig. 4. Calculated $a(\mathrm{MgO})-a\left(\mathrm{Al}_{2} \mathrm{O}_{3}\right)$ diagram. The arrow schematically represents changes in the marble approaching the skain front. The ruled area represents conditions! during formation of the outer skarn. The stippled area centered upon $a(\mathrm{MgO})=10^{-3.25}$ and $a\left(\mathrm{Al}_{2} \mathrm{O}_{3}\right)=10^{-1.7}$ and bounded by the by the stability limits of $\mathrm{Gr}(0.7)-\mathrm{Di}(0.5)$ represents conditions consistent with the average skarn compositions. Oxygen fugacities inferred from the exchange reaction (see text) are indicated on the right side of the figure. Oxygen fugacities inferred from these calculations are contoured in Fig. 5

has been located for the average garnet and pyroxene compositions as well as the end-member compositions. We are only interested in the segment of this line that lies in the area where garnet and pyroxene of the specified compositions are stable. This limits $a \mathrm{Al}_{2} \mathrm{O}_{3}$ to between $10^{-1.4}$ and $10^{-2}$ while $a \mathrm{MgO}$ is limited to $10^{-3.4}$ to $10^{-3}$. Similar limits could be derived for any garnet/pyroxene pair from the skarn.

In addition to constraining these two non-volatile activities, this figure also allows $f \mathrm{O}_{2}$ 's to be derived for any garnet/pyroxene pair. The reaction:

$2 \mathrm{CaFeSi}_{2} \mathrm{O}_{6}+\mathrm{Ca}_{3} \mathrm{Al}_{2} \mathrm{Si}_{3} \mathrm{O}_{12}+2 \mathrm{MgO}+1 / 2 \mathrm{O}_{2}$

$=2 \mathrm{CaMgSi}_{2} \mathrm{O}_{6}+\mathrm{Ca}_{3} \mathrm{Fe}_{2} \mathrm{Si}_{3} \mathrm{O}_{12}+\mathrm{Al}_{2} \mathrm{O}_{3}$

Hedenbergite + Grossular + Periclase $+1 / 20_{2}$

$=$ Diopside + Andradite + Corundum

when solved for a given garnet/pyroxene pair and for a specified $a \mathrm{MgO}$ and $a \mathrm{Al}_{2} \mathrm{O}_{3}$, yields a unique $f \mathrm{O}_{2}$. This equilibrium relation has been solved for the average compositions given above and three lines have been plotted corresponding to $\mathrm{fO}_{2}=10^{-22}, 10^{-23}$ and $10^{-24}$. The very acute intersection of these lines with those of reaction (15) yield a $f \mathrm{O}_{2}$ of $10^{-23}$ for the crossover (densely stippled) within the window described above, thus limiting the stability of the compositions specified. The simultaneous solution of these equations allows the $f \mathrm{O}_{2}$ to be specified for any garnet/pyroxene pair at a fixed $P-T$. This has been done for the range of compositions given in Fig. 2 and the $f \mathrm{O}_{2}$ contours are superimposed in Fig. 5. It can be readily seen that most of the compositions are consistent with $f \mathrm{O}_{2}$ 's between $10^{-22}$ and $10^{-24}$. In theory, this figure allows oxygen fugacities to be contoured across the skarn but scatter within samples usually obscures any short-range trends. This scatter is due to fluctuations in component activities and superposition of multiple generations - only the overall trends survive the scatter induced by so many chemical variables.

A figure of this general kind, without the explicit $f \mathrm{O}_{2}$

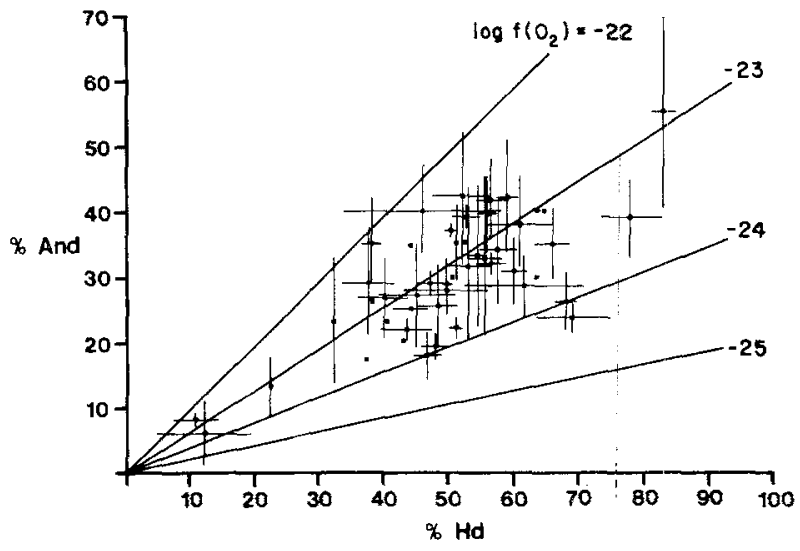

Fig. 5. Scatter diagram of garnet and pyroxene compositions with superimposed oxygen fugacities calculated as described in the text and Fig. 4

data, is presented in Einaudi (1977) (his Fig. 17) and is used to compare the relative oxidation states of tungsten, copper, and lead-zinc skarns. Einaudi et al. (1981) point out that copper and lead-zinc skarns are associated with more andraditic garnets $\left(\mathrm{Fe}^{+3}\right)$ and hence can be considered relatively oxidized compared to tungsten skarns which contain hedenbergite-rich pyroxene $\left(\mathrm{Fe}^{+2}\right)$. The $f \mathrm{O}_{2}$ data derived from this study support this conclusion of Einaudi (1977) and Zharikov (1970) with oxygen fugacities below QFM. The data in Fig. 5 also demonstrate the continuous, systematic variation in garnet and pyroxene compositions within a given skarn system, despite a significant total spread of analyses. The empirically derived limit of $\mathrm{X}(\mathrm{Hd})+\mathrm{X}(\mathrm{And})=1.1$ from Einaudi is also held to by all but two of the samples in Fig. 5. The total scatter of the analyses about their mean $f \mathrm{O}_{2}$ for the Pine Creek samples is similar in magnitude to that observed by Einaudi for the Mason Valley, Nevada copper skarn. This spread precludes making a definite statement about the relative importance of $f_{2}$ variations in controlling the skarn mineralogy; this point is discussed further below. 
Table 2. Summary of inferred component activities

\begin{tabular}{lcll}
\hline & Marble & Outer Skarn & \multicolumn{2}{l}{ Skarn } \\
\hline $\log f\left(\mathrm{O}_{2}\right)$ & $?$ & -25 to -22 & -24 to -22 \\
$\log a\left(\mathrm{Al}_{2} \mathrm{O}_{3}\right)$ & $<-2.0$ & $<-1.7$ & -2.0 to -1.4 \\
$\log a(\mathrm{CaO})$ & -5.0 & -5.7 to -5.5 & -6.0 to -5.7 \\
$\log a\left(\mathrm{Fe}_{2} \mathrm{O}_{3}\right)$ & $<-6.0$ & -6.0 to -3.9 & -3.9 to -3.0 \\
$\log a\left(\mathrm{MgO}^{2}\right.$ & -3.1 to -1.2 & -3.2 & -3.5 to -3.0 \\
$\log a\left(\mathrm{WO}_{3}\right)$ & $<-5.0$ & $<-5.0$ & -5.0 to -4.7 \\
\hline
\end{tabular}

As summarized in Table $2, \mathrm{MgO}$ activities decrease toward the igneous rock while $a \mathrm{Al}_{2} \mathrm{O}_{3}$ is increasing. Fairly tight ranges in these activities can be specified for any pair of garnet/pyroxene analyses or sequence of analyses. However the local short-range trends are usually lost in the scatter and only the overall trends given in Table 2 are really meaningful. This conclusion will be further supported below when a specific traverse is studied in detail.

\section{$\mathrm{Fe}_{2} \mathrm{O}_{3}$ activities}

Figure 6 is an $a \mathrm{Fe}_{2} \mathrm{O}_{3}-a \mathrm{Al}_{2} \mathrm{O}_{3}$ diagram calculated for selected equilibria which build on information from Fig. 4. The familiar limits on garnet stability from Fig. 4 again delimit metasomatic conditions. Because the activity of $\mathrm{Fe}_{2} \mathrm{O}_{3}$ is now being considered, the analogous reaction to:

$3 \mathrm{CaSiO}_{3}+\mathrm{Al}_{2} \mathrm{O}_{3}=\mathrm{Ca}_{3} \mathrm{Al}_{2} \mathrm{Si}_{3} \mathrm{O}_{12}$

Wollastonite + Corundum $=$ Grossular

may be written for andradite:

$3 \mathrm{CaSiO}_{3}+\mathrm{Fe}_{2} \mathrm{O}_{3}=\mathrm{Ca}_{3} \mathrm{Fe}_{2} \mathrm{Si}_{3} \mathrm{O}_{12}$

Wollastonite + Hematite $=$ Andradite

These reactions are the two end-members of a continuous reaction that can be solved for any intermediate garnet composition. The curved line in Fig. 6, asymptotically approaching reactions (17) and (18), is the locus of solutions for the general reaction:

$3 \mathrm{CaSiO}_{3}+x \mathrm{Al}_{2} \mathrm{O}_{3}+(1-\mathrm{x}) \mathrm{Fe}_{2} \mathrm{O}_{3}$

$=\mathrm{Ca}_{3} \mathrm{Al}_{2} \mathrm{Si}_{3} \mathrm{O}_{12}(\mathrm{x}) \mathrm{Ca}_{3} \mathrm{Fe}_{2} \mathrm{Si}_{3} \mathrm{O}_{12}(1-\mathrm{x})$.

Wollastonite + Corundum + Hematite $=$ Garnet

Finally, the family of lines on the right-hand side of the diagram corresponds to the various $\mathrm{fO}_{2}$ solutions for the reaction:

$2 \mathrm{Ca}_{3} \mathrm{Fe}_{2} \mathrm{Si}_{3} \mathrm{O}_{12}+6 \mathrm{SiO}_{2}+\mathrm{Fe}_{2} \mathrm{O}_{3}=6 \mathrm{CaFeSi}_{2} \mathrm{O}_{6}+3 / 20_{2}(20)$

Andradite + Quartz + Hematite $=$ Hedenbergite $+3 / 20_{2}$

for the average garnet/pyroxene compositions.

No meaningful lower limits for these components may be assigned to the marbles. However, for the outer and inner skarn zones, this diagram becomes useful. After the formation of wollastonite, $\mathrm{Al}_{2} \mathrm{O}_{3}$ activities eventually became high enough to produce garnet which is initially nearly pure grossular $\left(a \mathrm{Al}_{2} \mathrm{O}_{3}=10^{-1.7}\right)$ while $a \mathrm{Fe}_{2} \mathrm{O}_{3}$ is less than $10^{-6}$. As the outer skarn is replaced by the massive garnet skarn, the $\mathrm{Fe}_{2} \mathrm{O}_{3}$ activity rises steadily along the curved line until all the wollastonite has reacted away and the composition of the system is no longer buffered by reaction (19). Conditions then track up into the region indicated by the stippling. The heavily stippled portion corresponds to the previously determined $\mathrm{fO}_{2}$ range (Fig. 4) and encompasses a fairly broad range for $a \mathrm{Fe}_{2} \mathrm{O}_{3}=10^{-3}$ to $10^{-3.8}$. There is no good upper limit on $\mathrm{Fe}_{2} \mathrm{O}_{3}$ activities given the mineralogy; the limits are best supplied by the $f \mathrm{O}_{2}$ restrictions derived earlier. A limited range of permissible activities and a well-quantified trend from the marble, through the outer skarn and into the garnet unit is shown in Fig. 4 and Table 2 .

\section{$\mathrm{WO}_{3}$ activities}

In considering scheelite, a new problem arises - that of the time of deposition of the ore material with respect to the associated silicates. Evidence from Pine Creek (Wright

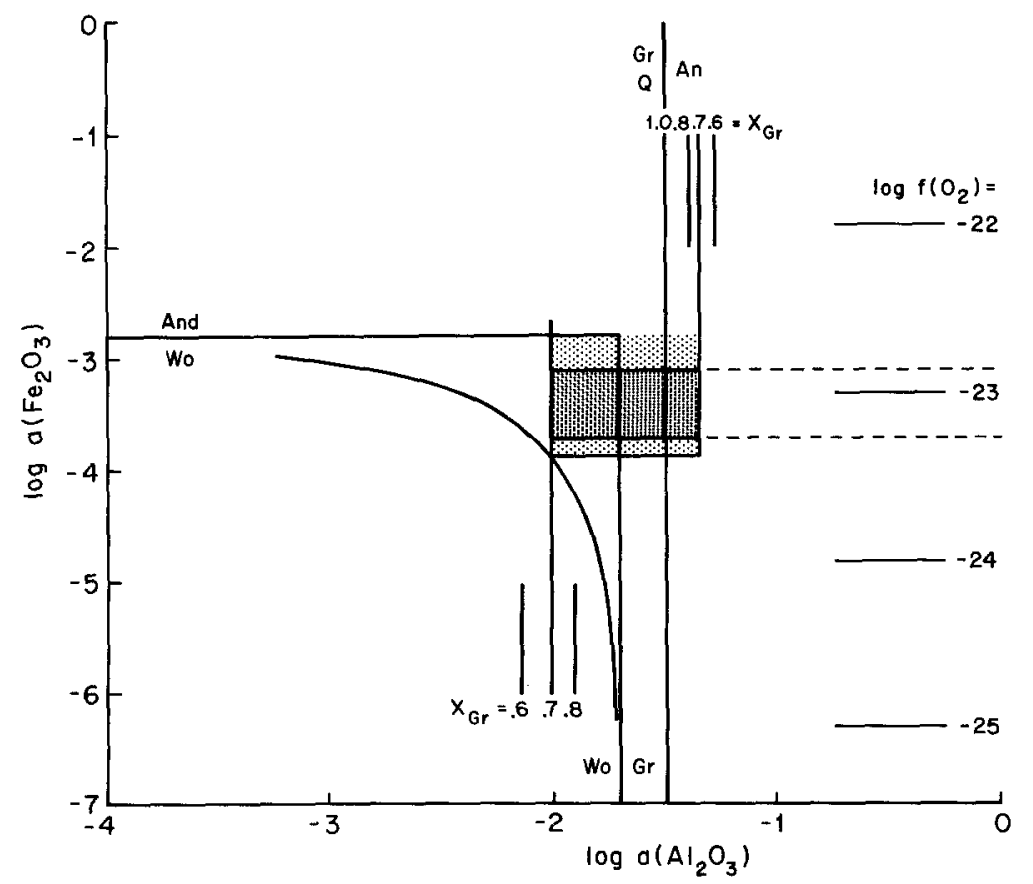

Fig. 6. Calculated $a\left(\mathrm{Fe}_{2} \mathrm{O}_{3}\right)-a\left(\mathrm{Al}_{2} \mathrm{O}_{3}\right)$ diagram. The curving line rising from low $\mathrm{Fe}_{2} \mathrm{O}_{3}$ activities represents conditions in the outer-skarn for reaction (19) in the text. The stippled area covers the range of conditions for the ore-bearing skarn with the densely stippled area having upper and lower bounds calculated using the $f\left(\mathrm{O}_{2}\right)$ data from Figs. 4 and 5 


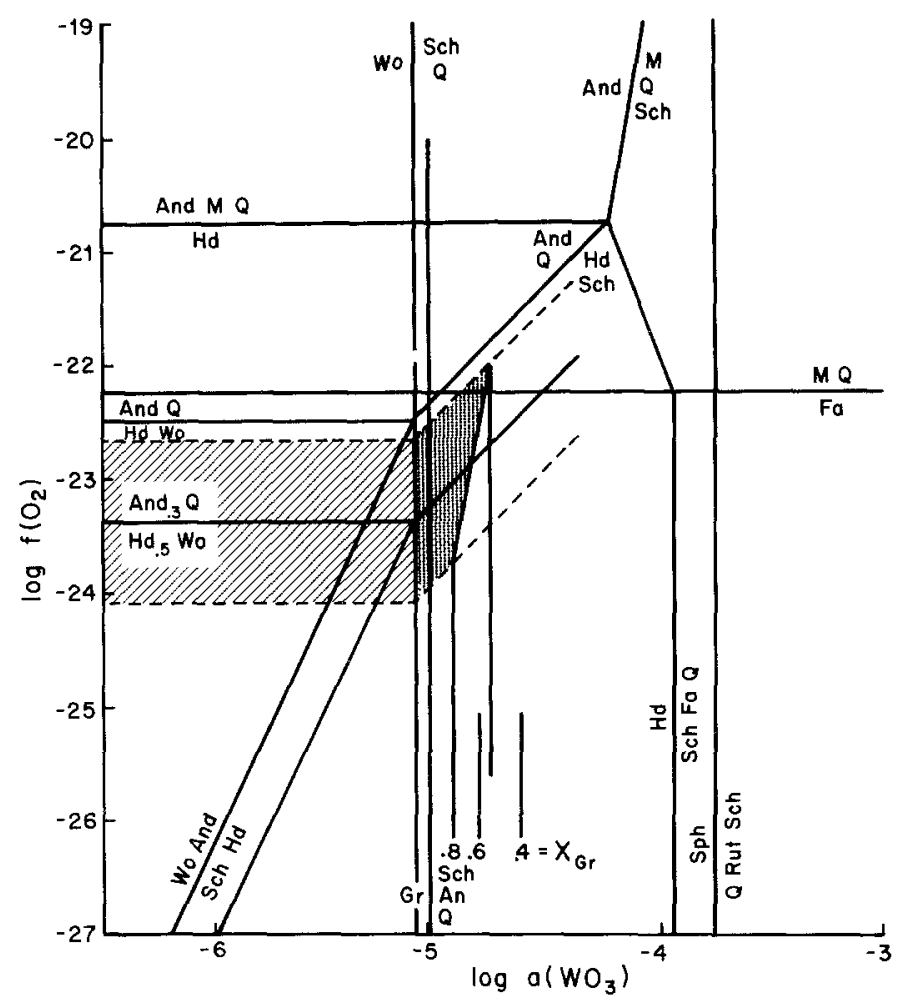

Fig. 7. Calculated $f\left(\mathrm{O}_{2}\right)-a\left(\mathrm{WO}_{3}\right)$ diagram. The area to the left of the wollastonite breakdown curve represents conditions in the outermost barren skarn. The stippled field covers possible conditions consistent with the ore-bearing skarn

1973; Newberry 1980, 1982; Brown 1980) as well as other tungsten deposits (Morgan 1975; Taylor 1976; Kwak 1978) indicates that the bulk of the scheelite (as presently found) was deposited following main-stage skarn development. There is scheelite deposition throughout (time) but the majority of the ore may be remobilized early scheelite. Scheelite exhibits a retrograde solubility in the temperature range $400-500^{\circ} \mathrm{C}$ at low pressures (Krumhansl 1977). This dissolution-redeposition behavior with falling temperature helps account for the differences in powellite contents of the early- and late-formed scheelite. The early-formed grains, often preserved in garnet or pyroxene crystals or overgrown by late-scheelite, have high molybdenum contents $(10-20 \%$ $\mathrm{CaMoO}_{4}$ ) (Wright 1973). The later scheelite is low in Mo $\left(0-3 \% \mathrm{CaMoO}_{4}\right)$, the molybdenum being present now as molybdenite and indicative of the higher sulfur fugacities at the time of remobilization. In the following discussion the scheelite will be considered to be in thermodynamic equilibrium with the the enclosing silicates and thus treatable in the same way as other phases. No quantitative treatment will be given the powellite solid solution except to note that small amounts of Mo will extend, somewhat, the stability of the scheelite-bearing assemblages.

With the above qualifications in mind, Fig. 7 is a $\mathrm{fO}_{2}-$ $a \mathrm{WO}_{3}$ plot showing the possible fields of the outer and garnet skarns. The assemblage wollastonite-scheelite-quartz found in a number of specimens from very near the inner/ outer skarn boundary is very restrictive to $a \mathrm{WO}_{3}=10^{-5.1}$. If pyroxene and garnet are also present, a unique $f \mathrm{O}_{2}$ is also determined, and a very small range of $\mathrm{WO}_{3}$ activities is permissible for the skarn assemblages as anorthite is not present. A more detailed discussion of the figure will be given below with a synthesis of skarn and ore formation.

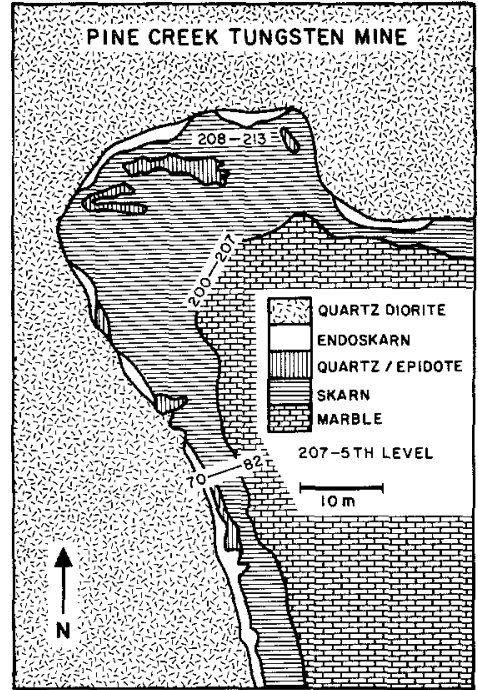

Fig. 8. Geologic map of the 207-5th mining sublevel with sample traverse locations. The outer-skarn occurs everywhere at the marble-skarn interface but is too narrow to be shown at this scale. Geologic mapping is by both the author and Pine Creek geologists

\section{The 207-5th mining level: an example}

The diagrams and generalities developed in the preceding sections have been applied to several traverses across the Pine Creek ore body to test the applicability of the figures and to determine whether a smaller number of analyses will indeed yield trends for some of the activities. Figure 8 is a simplified geologic map of the 207-5th mining sublevel, the traverses and sample numbers are located on the map. This level is located in the upper portions of the mine and is developed in a reentrant of the marble into the intrusive, here a more mafic quartz-diorite phase of the MCQM. The iron-poor outer skarn zone is present everywhere at the marble/skarn contact but the scale of the figure does not permit it to be shown. Pyroxene-rich skarn occurs in this area and has been mapped as a separate unit. Scheelite is present throughout the skarn and does not noticeably correlate with either the "normal" or "high pyroxene" variety of skarn. This part of the mine has abundant chalcopyrite and molybdenite as accessory phases and above-average silver values although little is known about the host for the silver. The quartz/epidote unit is extensively developed on this level and is post-main-stage as shown by its transgressive nature.

Table 3 is a compilation of garnet and pyroxene analyses along the traverses (analytical data are given in Brown 1980). Each of the values in Table 3 is a weighted average of between 2 and 40 separate analyses. The averages were weighted by consideration of alteration and, where possible, core/rim relationships. In addition, Table 3 presents the inferred "non-volatile" activities for each of the components discussed in the previous sections of this paper. Finally, Fig. 9 graphically shows the trends of garnet and pyroxene compositions along the traverses.

The garnet and pyroxene compositional trends in Fig. 9 display several distinct patterns. Figure 9 a exhibits the sharp compositional break at the marble/outer skarn boundary and a slight increase in hedenbergite content for the pyroxene as the intrusive is approached. In general, however, the analyses show a fairly constant iron content for both the garnets and the pyroxenes across the skarn 
Table 3. Garnet and pyroxene analyses and inferred component activities

\begin{tabular}{|c|c|c|c|c|c|c|c|c|c|}
\hline $\begin{array}{l}\text { Rock }^{a} \\
\text { Type }\end{array}$ & $\begin{array}{l}\text { Samp. } \\
\text { No. }\end{array}$ & $\begin{array}{l}\% \mathrm{Hd} \\
\pm 5\end{array}$ & $\begin{array}{l}\% \text { And } \\
\pm 7\end{array}$ & $\begin{array}{l}-\log f(\mathrm{O}) \\
\pm 0.2\end{array}$ & $-\log a(\mathrm{MgO})$ & $-\log a\left(\mathrm{Al}_{2} \mathrm{O}_{3}\right)$ & \multicolumn{2}{|c|}{$\begin{array}{ll}-\log a(\mathrm{CaO}) & -\log \\
\pm 0.1 & a\left(\mathrm{Fe}_{2} \mathrm{O}_{3}\right)^{\mathbf{b}} \\
& \pm 0.3\end{array}$} & $\begin{array}{l}-\log \\
a\left(\mathrm{WO}_{3}\right)\end{array}$ \\
\hline Sk & 72 & 45 & 30 & 23.0 & $3.4-3.2$ & $2.0-1.4$ & 5.8 & 3.6 & \\
\hline $\mathrm{Sk}$ & 73 & 55 & 38 & 22.8 & $3.5-3.2$ & $2.1-1.3$ & 5.9 & 3.2 & \\
\hline $\mathrm{Sk}$ & 74 & 65 & 42 & 22.9 & $3.6-3.3$ & $2.2-1.3$ & 5.9 & 3.0 & $4.9-5.1$ \\
\hline $\mathrm{Sk}$ & 75 & 55 & 41 & 22.7 & $3.5-3.2$ & $2.2-1.3$ & 5.9 & 3.1 & \\
\hline $\mathrm{Sk}$ & 76 & 62 & 45 & 22.7 & $3.6-3.2$ & $2.2-1.2$ & 5.9 & 3.0 & $4.9-5.1$ \\
\hline $\mathrm{Sk}$ & 77 & 59 & 37 & 23.0 & $3.5-3.3$ & $2.1-1.3$ & 5.9 & 3.2 & $4.9-5.1$ \\
\hline $\mathrm{Sk}$ & 78 & 46 & 27 & 23.2 & $3.4-3.2$ & $2.0-1.4$ & 5.8 & 3.6 & $4.9-5.1$ \\
\hline OS & 79 & 47 & $(10)$ & $(25.1)$ & $3.4-3.3$ & $1.8-1.5$ & 5.7 & 4.7 & $4.9-5.1$ \\
\hline OS & 80 & 22 & (10) & $(23.7)$ & $3.2-3.1$ & $1.8-1.5$ & 5.8 & 4.6 & \\
\hline $\mathrm{Mbl}$ & 81 & 8 & - & & 3.2 & 1.7 & 5.5 & $<6.0$ & \\
\hline $\mathrm{Mbl}$ & 82 & 4 & - & & 3.2 & 1.7 & 5.5 & $<6.0$ & \\
\hline $\mathrm{Mbl}$ & 200 & 8 & - & & 3.2 & 1.7 & 5.5 & $<6.0$ & \\
\hline OS & 201 & 43 & - & & 3.4 & 1.7 & 5.7 & $>5.0$ & \\
\hline Sk & 202 & 50 & - & & 3.4 & 1.7 & 5.7 & $>5.0$ & \\
\hline Mbl & 203 & 9 & - & & 3.2 & 1.7 & 5.5 & $<6.0$ & \\
\hline $\mathrm{Sk}$ & 204 & 48 & 25 & 23.4 & $3.4-3.2$ & $2.0-1.4$ & 5.8 & 3.7 & \\
\hline Sk & 205 & 50 & 32 & 23.0 & $3.4-3.2$ & $2.0-1.3$ & 5.8 & 3.4 & \\
\hline Sk & 206 & 54 & 30 & 23.3 & $3.5-3.2$ & $2.0-1.3$ & 5.8 & 3.5 & \\
\hline $\mathrm{Sk}$ & 207 & 60 & 38 & 23.0 & $3.5-3.3$ & $2.1-1.3$ & 5.8 & 3.2 & \\
\hline Sk & 208 & 40 & 32 & 22.9 & $3.4-3.2$ & $2.0-1.3$ & 5.8 & 3.4 & \\
\hline Sk & 209 & 72 & 38 & 23.3 & $3.7-3.4$ & $2.1-1.3$ & 5.9 & 3.2 & $4.9-5.1$ \\
\hline $\mathrm{Sk}$ & 211 & 68 & 36 & 23.4 & $3.6-3.4$ & $2.1-1.3$ & 5.8 & 3.4 & \\
\hline $\mathrm{Sk}$ & 212 & 33 & 34 & 22.2 & $3.3-3.1$ & $2.1-1.3$ & 5.8 & 3.4 & \\
\hline Sk & 213 & 45 & 31 & 22.9 & $3.4-3.2$ & $2.0-1.3$ & 5.8 & 3.5 & \\
\hline
\end{tabular}

a Sk garnet skarn; OS outer skarn; Mbl marble

b The "less than" sign $(<)$ means less than the negative number, i.e., $<6$ could be $\log a(\mathrm{X})=-7$
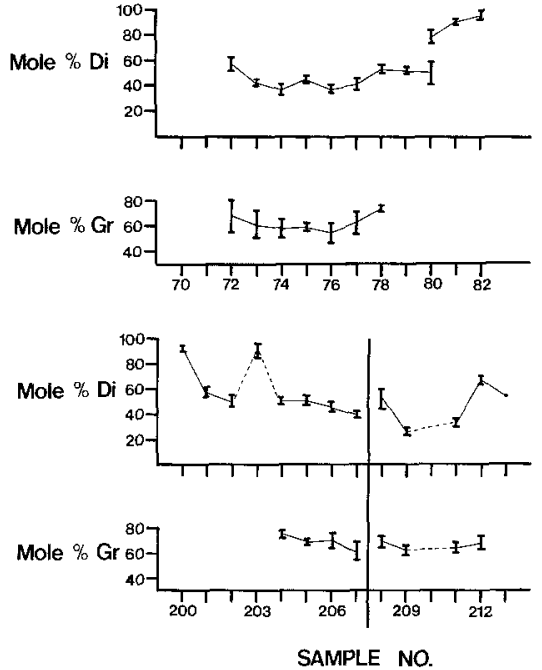

Fig. 9. Garnet and pyroxene compositions across the orebody for the samples shown in Fig. 8. The vertical bars represent the ranges of compositions for the individual samples

with a marked decrease in the endoskarn. There are some anomalous samples (\#203) which do not fit into the sequence for the traverse and these will be largely ignored in the following discussion. Finally, even considering total scatter for the analyses, some of the traverses here and elsewhere in the mine are associated with slight decreases in the iron contents of the pyroxenes and the garnets toward the intrusive.
In addition to variations in the activities of the many chemical species involved in skarn formation, changes in the absolute amounts of various elements critically affect the final mineralogy and proportions of the phases. A computer program was written to calculate average bulk compositions for a given specimen or zone utilizing average mineral compositions and modal analyses.

The program also calculates the absolute additions or subtractions of components from a given volume of rock during the metasomatic transformation. Table 4 presents the results of these calculations for one of the traverses for the 207-5th. The values in Table 5 demonstrate the importance of considering volume changes during the metasomatic event. Extreme volume changes may actually reverse the inferred direction of net transport for a component. There is no evidence at Pine Creek for such extreme volume changes and in general the metasomatic event probably produced less than a $5 \%$ decrease in volume. This decrease is exhibited in the rocks as an increased porosity, now filled with minor quartz and calcite. It is not possible to evaluate this net volume change quantitatively due to, for instance, the absence of marker beds in the original sediments which could be traced into the skarn and allow actual volume changes to be calculated. The results in Table 4 do indicate that significant additions of silicon, aluminum, iron, magnesium, manganese and tungsten have accompanied skarn formation and that calcium and $\mathrm{CO}_{2}$ have been removed. Consideration of the average thicknesses of the units coupled with the data in Table 4 further indicates that the endoskarn cannot be the source for more than a small percentage of the material added to the skarn. 
Table 4. Mass balance calculations

\begin{tabular}{|c|c|c|c|c|c|c|c|c|}
\hline & \multirow{2}{*}{$\begin{array}{l}\text { Marble } \\
\text { initial } \\
\text { composition }\end{array}$} & \multicolumn{2}{|c|}{ Marble $\rightarrow$ Calc-silicate } & \multicolumn{2}{|c|}{ Marble $\rightarrow$ skarn } & \multicolumn{3}{|c|}{ Quartz monzonite $\rightarrow$ endoskarn } \\
\hline & & $\begin{array}{l}\text { Final } \\
\text { composition }\end{array}$ & $\begin{array}{l}\text { Percent } \\
\text { change }\end{array}$ & $\begin{array}{l}\text { Final } \\
\text { composition }\end{array}$ & $\begin{array}{l}\text { Percent } \\
\text { change }\end{array}$ & $\begin{array}{l}\text { Initial } \\
\text { composition }\end{array}$ & $\begin{array}{l}\text { Final } \\
\text { composition }\end{array}$ & $\begin{array}{l}\text { Percent } \\
\text { change }\end{array}$ \\
\hline $\mathrm{SiO}_{2}$ & 22.20 & 67.47 & 203.96 & 160.38 & 622.52 & 190.42 & 193.99 & 1.87 \\
\hline $\mathrm{TiO}_{2}^{2}$ & 1.14 & 1.14 & $1,308.19$ & 0.00 & -100.00 & 2.50 & 1.43 & -42.97 \\
\hline $\mathrm{Al}_{2} \mathrm{O}_{3}$ & 1.13 & 15.92 & 0.00 & 27.29 & $2,313.15$ & 34.74 & 34.31 & -1.23 \\
\hline $\mathrm{Fe}_{2} \mathrm{O}_{3}$ & 0.00 & 1.18 & $\infty$ & 16.50 & $\infty$ & 0.00 & 0.00 & 0.00 \\
\hline $\mathrm{FeO}$ & 4.73 & 4.81 & 1.82 & 22.69 & 379.75 & 10.33 & 2.58 & -75.05 \\
\hline $\mathrm{MnO}$ & 0.10 & 0.50 & 400.00 & 5.60 & $5,477.43$ & 0.00 & 0.00 & 0.00 \\
\hline $\mathrm{MgO}$ & 5.39 & 8.72 & 61.66 & 14.38 & 166.67 & 2.43 & 3.90 & 60.03 \\
\hline $\mathrm{CaO}$ & 139.91 & 130.44 & -6.77 & 99.61 & -28.80 & 2.78 & 14.00 & 403.16 \\
\hline $\mathrm{Na}_{2} \mathrm{O}$ & 0.00 & 0.00 & 0.00 & 0.00 & 0.00 & 7.74 & 6.19 & -20.00 \\
\hline $\mathrm{K}_{2} \mathrm{O}$ & 0.86 & 0.00 & -100.00 & 0.00 & -100.00 & 15.66 & 12.94 & -17.34 \\
\hline $\mathrm{H}_{2} \mathrm{O}$ & 0.03 & 1.23 & $3,450.52$ & 0.00 & -100.00 & 1.04 & 0.00 & -100.00 \\
\hline $\mathrm{CO}_{2}$ & 102.48 & 61.96 & -39.53 & 0.00 & -100.00 & 0.00 & 0.00 & 0.00 \\
\hline $\mathrm{WO}_{3}^{2}$ & 0.00 & 0.00 & 0.00 & 2.31 & $\infty$ & 0.00 & 0.00 & 0.00 \\
\hline $\mathrm{SO}_{2}$ & 3.39 & 0.00 & -100.0 & 0.00 & -100.00 & 0.00 & 0.00 & 0.00 \\
\hline
\end{tabular}

* Zero percent volume change is assumed for these calculations*

Table 5. Volume effect on mass balance calculations

\begin{tabular}{|c|c|c|c|c|c|c|c|}
\hline & \multicolumn{7}{|c|}{ Marble $\rightarrow$ Skarn } \\
\hline & \multirow{2}{*}{$\begin{array}{l}\text { Marble } \\
\text { initial } \\
\text { composition }\end{array}$} & \multicolumn{2}{|c|}{$0 \%$ volume change } & \multicolumn{2}{|c|}{$10 \%$ volume change } & \multicolumn{2}{|c|}{$20 \%$ volume change } \\
\hline & & $\begin{array}{l}\text { Final } \\
\text { composition }\end{array}$ & $\begin{array}{l}\text { Percent } \\
\text { change }\end{array}$ & $\begin{array}{l}\text { Final } \\
\text { composition }\end{array}$ & $\begin{array}{l}\text { Percent } \\
\text { change }\end{array}$ & $\begin{array}{l}\text { Final } \\
\text { composition }\end{array}$ & $\begin{array}{l}\text { Percent } \\
\text { change }\end{array}$ \\
\hline $\mathrm{SiO}_{2}$ & 22.20 & 160.38 & 622.52 & 144.34 & 550.27 & 128.30 & 478.02 \\
\hline $\mathrm{TiO}_{2}^{2}$ & 1.14 & 0.00 & -100.00 & 0.00 & -100.00 & 0.00 & -100.00 \\
\hline $\mathrm{Al}_{2} \mathrm{O}_{3}$ & 1.13 & 27.29 & $2,313.15$ & 24.56 & $2,071.84$ & 21.83 & $1,830.52$ \\
\hline $\mathrm{Fe}_{2} \mathrm{O}_{3}$ & 0.00 & 16.50 & $\infty$ & 14.85 & $\infty$ & 13.20 & $\infty$ \\
\hline $\mathrm{FeO}$ & 4.73 & 22.69 & 379.75 & 20.42 & 331.78 & 18.15 & 283.00 \\
\hline $\mathrm{MnO}$ & 0.10 & 5.60 & $5,477.43$ & 5.04 & $4,919.68$ & 4.48 & $4,361.94$ \\
\hline $\mathrm{MgO}$ & 5.39 & 14.38 & 166.67 & 12.95 & 140.00 & 11.51 & 113.33 \\
\hline $\mathrm{CaO}$ & 139.91 & 99.61 & -28.80 & 89.65 & -35.92 & 79.69 & -43.04 \\
\hline $\mathrm{Na}_{2} \mathrm{O}$ & 0.00 & 0.00 & 0.00 & 0.00 & 0.00 & 0.00 & 0.00 \\
\hline $\mathrm{K}_{2} \mathrm{O}$ & 0.86 & 0.00 & -100.00 & 0.00 & -100.00 & 0.00 & -100.00 \\
\hline $\mathrm{H}_{2} \mathrm{O}$ & 0.03 & 0.00 & -100.00 & 0.00 & -100.00 & 0.00 & -100.00 \\
\hline $\mathrm{CO}_{2}$ & 102.48 & 0.00 & -100.00 & 0.00 & -100.00 & 0.00 & -100.00 \\
\hline $\mathrm{WO}_{3}$ & 0.00 & 2.31 & $\infty$ & 2.08 & $\infty$ & 1.85 & $\infty$ \\
\hline $\mathrm{SO}_{2}{ }^{3}$ & 3.39 & 0.00 & -100.00 & 0.00 & -100.00 & 0.00 & -100.00 \\
\hline
\end{tabular}

*All compositions are given in grams*

\section{Discussion}

Only the large-scale trends and major compositional discontinuities are separable from the small-scale scatter in the inferred component activities (Table 3). The major factor causing this scatter is the thermodynamically underdetermined nature of the skarn system where the number of phases is considerably less than the number of components. Geologically, this suggests that variations in the amount (rate) of reaction and non-uniform compositions of both the host rocks and the infiltrating solutions resulted in the observed scatter. This prevents solving for unique activities of, for instance, $\mathrm{Al}_{2} \mathrm{O}_{3}$ or $\mathrm{MgO}$. An additional problem is that the spread of analyses for a given sample is often as wide as the entire variation across the skarn. This zoning and apparent lack of equilibrium between the garnets and pyroxenes is examined in more detail in a companion publi- cation analyzing stable isotope data for the skarn system (Brown et al. 1985).

For the 207-5th level, the data support the same ranges and limits as are summarized in Table 2 for the skarn as a whole with no single variable controlling either mineralogy or composition. A possible correlation between the presence of scheelite and $f \mathrm{O}_{2}$ may be deduced from Eq. (21). A slightly higher $\mathrm{fO}_{2}$ may locally cross the reaction:

$2 \mathrm{Hd}+\mathrm{Sch}+1 / 2 \mathrm{O}_{2}=\mathrm{And}+\mathrm{Q}+\mathrm{WO}_{3}$

Hedenbergite + Scheelite $+1 / 20_{2}=$ Andradite + Quartz + $\mathrm{WO}_{3}$

destabilizing the scheelite. However, uncertainties in the magnitudes of the changes in the activities and other variables which cannot presently be quantified preclude any definite conclusions for this example. 
The treatment of the various non-volatile component activities pursued in this paper demonstrates that trends are evident for the metasomatic system as a whole. Consideration of these variables and trends are as important as the more usual discussions of volatile component activities and fugacities. While general trends are obvious, the small activity changes accompanying profound compositional changes in solid solutions indicate the difficulty of trying to determine which variables are independent and which are dependent. Mass balance considerations attempting to estimate the material transported will be complicated by the strong zoning in garnets and pyroxenes. Further, it is clear that no single variable controls skarn formation or the occurrence of ore.

Figure 7 indicates that the presence of scheelite in a quartz saturated environment at $1.5 \mathrm{kbars}$ and $800 \mathrm{~K}$ necessitates an activity of $\mathrm{WO}_{3}$ greater than $10^{-5.1}$. However, it is uncertain what controls the presence or absence of ore in any given volume of garnet/pyroxene skarn. The figure shows that garnet skarn generally has a slightly higher $a \mathrm{WO}_{3}=10^{-4.95 \pm 0.15}$ but this does not give an unique ore control. A lack of ore may reflect locally lower $a \mathrm{WO}_{3}$ or a slightly higher $f \mathrm{O}_{2}$, crossing reaction (21). The simple calculation for the reaction:

$\mathrm{Sch}=\mathrm{CaO}+\mathrm{WO}_{3}$

Scheelite $=\mathrm{Lime}+\mathrm{WO}_{3}$

gives the result:

$-10.78=\log a \mathrm{WO}_{3}+\log a \mathrm{CaO}$.

Thus $a \mathrm{CaO}$ may control the presence or absence of ore; the very andradite-rich garnets are associated with lower $a \mathrm{CaO}$ (Fig. 2) and would perhaps require higher $\mathrm{WO}_{3}$ activities than were obtained to allow ore deposition. Variations in $\mathrm{MgO}$ and/or $\mathrm{Al}_{2} \mathrm{O}_{3}$ activities require changes in pyroxene and garnet compositions that yield changes in $\mathrm{fO}_{2}$ (Fig. 4). Thus these variables may control ore deposition as readily as the others already discussed.

Therefore, while ore deposition may simply be a result of increased availability of tungsten, details in its distribution and abundance from place to place within a deposit. are also strongly affected by slight variations in $f \mathrm{O}_{2}, a \mathrm{CaO}$, $a \mathrm{Al}_{2} \mathrm{O}_{3}, a \mathrm{MgO}$ and $a \mathrm{Fe}_{2} \mathrm{O}_{3}$ as well. The interrelationships of these factors yields a tightly woven web with no apparent independent strands. Thus, at this time, it is not possible to derive a simple criterion controlling the presence or absence of scheelite in a garnet/pyroxene skarn. Assuming equilibrium conditions prevailed however, it is possible to list chemical parameters consistent with the presence of ore (Table 2) for this $P-T$, as well as physically observable mineralogical criteria suggesting the presence or absence of ore. Some of these are listed below, and others may be derived from the activity plots given in this study.

The Pine Creek skarns are typified by the presence of sphene and the absence of plagioclase and iron oxides. Sphene is the dominant titanium-bearing phase and implies silica and lime activities are high enough to destabilize rutile and perovskite (Fig. 3). This level of $a \mathrm{CaO}$ allowed scheelite to form at $a \mathrm{WO}_{3}=10^{-5.1}$; lower $a \mathrm{CaO}$ would have required higher $\mathrm{WO}_{3}$ activities, perhaps higher than could be obtained in the skarn environment. These theoretically higher $\mathrm{WO}_{3}$ and lower $\mathrm{CaO}$ activities would be accompanied by either more andraditic garnet or the presence of plagioclase. The absence of plagioclase follows from Figs. 6 and 7 and the assumptions that 1) wollastonite is present, 2) that the solution is not supersaturated and 3) that equilibrium is maintained. The absence of main-stage primary iron oxides can be explained because the presence of magnetite would require either a higher $\mathrm{fO}_{2}$ or a large increase in the $a \mathrm{Fe}_{2} \mathrm{O}_{3}$ which would increase the andradite component in the garnet and lower the $\mathrm{CaO}$ activity, again requiring higher $\mathrm{WO}_{3}$ activities to stabilize scheelite.

Other generalities may be extracted from the activity diagrams presented above. The predictive power for determining whether or not a given skarn will bear scheelite is limited by the interrelationships of the variables. The decrease or increase of the activity of a single component may be offset by the complementary change of another yielding an environment that, though different from Pine Creek, may still bear scheelite. Thus the study of non-volatile component activities, while not producing an easily applicable exploration tool, can begin to describe the skarn and ore-forming stages for a given deposit and can be used with chemical data to limit ore possiblities for other parts of a given deposit.

Acknowledgments. This paper represents a portion of the senior author's Ph.D. Thesis at The University of Michigan. The guidance of W.C. Kelly and his invaluable comments and direction are gratefully acknowledged. Access to the study area was graciously granted by Union Carbide Corporation. John Trammell, Raymond Posner and William Durbin are especially thanked for their time and interest. Free access to maps and assay results as well as the mine workings were crucial to this study. Financial support was provided by Union Carbide Corporation, the Scott Turner Fund, a teaching fellowship and Rackham Scholarship from the University of Michigan and an NSF dissertation grant EAR-79-16865. Earlier drafts of portions of this manuscript greatly benefited from critical reviews by J.R. Bowman, D.R. Peacor and J.W. Valley.

\section{References}

Bateman PC (1965) Geology and tungsten mineralization of the Bishop District, California. US Geol Surv Prof Paper 470:208

Bird DK, Helgeson HC (1980) Chemical interaction of aqueous solutions with epidote-feldspar mineral assemblages in geologic systems. 1. Thermodynamic analysis of phase relations in the system $\mathrm{CaO}-\mathrm{FeO}-\mathrm{Fe}_{2} \mathrm{O}_{3}-\mathrm{Al}_{2} \mathrm{O}_{3}-\mathrm{SiO}_{2}-\mathrm{H}_{2} \mathrm{O}-\mathrm{CO}_{2}$. Am J Sci 280:907-941

Bohlen SR, Essene EJ (1978) The significance of metamorphic fluorite in the Adirondacks. Geochim Cosmochim Acta 42:1669-1678

Bowman JR (1978) Contact metamorphism, skarn formation, and origin of $\mathrm{C}-\mathrm{O}-\mathrm{H}$ skarn fluids in the Black Butte aureole, Elkhorn, Montana. Unpub PhD thesis, Univ Michigan

Bowman JR, Essene EJ (1984) Contact skarn formation at Elkhorn Montana $\mathrm{I} ; P-T$-component activity conditions of early skarn formation. Am J Sci 284:597-650

Brown PE (1980) A petrologic and stable isotopic study of skarn formation and mineralization at the Pine Creek, California tungsten mine. Unpub $\mathrm{PhD}$ thesis, Univ Michigan

Brown PE, Bowman JR, Kelly WC (1985) Petrologic and stable isotopic constraints on the source and evolution of skarn-forming fluids at Pine Creek, California. Econ Geol 80:72-95

Burt DM (1971 a) Some phase equlibria in the system $\mathrm{Ca}-\mathrm{Fe}-$ $\mathrm{Si}-\mathrm{C}-\mathrm{O}$. Carnegie Inst Wash Year Book 70:178-184

Burt DM (1971 b) The facies of some $\mathrm{Ca}-\mathrm{Fe}-\mathrm{Si}$ skarns in Japan. Carnegie Inst Wash Year Book 70:185-188

Burt DM (1972a) The influence of fluorine on the facies of $\mathrm{Ca}-$ $\mathrm{Fe}-\mathrm{Si}$ skarns. Carnegie Inst Wash Year Book 71:443-450 
Burt DM (1972b) Silicate-sulfide equilibria in $\mathrm{Ca}-\mathrm{Fe}-\mathrm{Si}$ skarn deposits. Carnegie Inst Wash Year Book 71:450-457

Burt DM (1978) Multisystems analysis of beryllium mineral stabilities: The system $\mathrm{BeO}-\mathrm{Al}_{2} \mathrm{O}_{3}-\mathrm{SiO}_{2}-\mathrm{H}_{2} \mathrm{O}$. Am Mineral 63:664 676

Burton JC, Taylor LA, Chou IM (1982) The $f\left(\mathrm{O}_{2}\right)-T$ and $f\left(\mathrm{~S}_{2}\right)-$ $T$ stability relations of hedenbergite and of hedenbergite-johannsenite solid solutions. Econ Geol 77:764-783

Carmichael ISE, Turner FJ, Verhoogen J (1974) Igneous Petrology. McGraw-Hill Book Co, New York, pp 50-59

Charlu TV, Newton RC, Kleppa OJ (1978) Enthalpy of some lime silicates by high temperature solution calorimetry with discussion of high pressure phase equilibria. Geochim Cosmochim Acta $42: 367-375$

Cressey G, Schmid R, Wood BJ (1978) Thermodynamic properties of almandine-grossular garnet solid solutions. Contrib Mineral Petrol 55:397-404

Einaudi MT (1977) Petrogenesis of copper-bearing skarn at the Mason Valley mine, Yerington district, Nevada. Econ Geol 72:769-795

Einaudi MT, Meinert LD, Newberry RJ (1981) Skarn deposits. Econ Geology, 75th Anniv Vol:317-391

Froese E, Gordon TM (1974) Activity coefficients of coexisting pyroxenes. Am Mineral 59:204-205

Gamble RP (1982) An experimental study of sulfidation reactions involving andradite and hedenbergite. Econ Geol 77:784-797

Ganguly J (1976) The energetics of natural garnet solid solution II. Mixing of the calcium silicate end-members. Contrib Mineral Petrol 55:81-90

Ganguly J, Kennedy GC (1974) The energetics of natural garnet solid solutions. I. Mixing of the aluminosilicate end-members. Contrib Mineral Petrol 48:137-148

Gustafson W (1974) The stability of andradite, hedenbergite and related minerals in the system $\mathrm{Ca}-\mathrm{Fe}-\mathrm{Si}-\mathrm{O}-\mathrm{H}$. J Petrol 15:455-496

Helgeson HC, Delany JM, Nesbitt HW, Bird DK (1978) Summary and critique of the thermodynamic properties of rock-forming minerals. Am J Sci 178-A: 1-229

Hensen BJ, Schmid R, Wood BJ (1975) Activity-composition relationships for pyrope-grossular garnet. Contrib Mineral Petrol $51: 151-166$

Huckenholz HG, Lindhuber W, Fehr KT (1981) Stability relationships of grossular + quartz + wollastonite + anorthite . The effect of andradite and albite. Neues Jahrb Mineral Abh $142: 223-247$

Krumhansl JL (1977) Geochemistry of tungsten. Unpub PhD thesis, Stanford Univ

Kwak TAP (1978) The conditions of formation of the King Island scheelite contact skarn, King Island, Tasmania, Australia. Am J Sci 278:969-999
Liou JG (1974) Stabilitiy relations of andradite-quartz in the system $\mathrm{Ca}-\mathrm{Fe}-\mathrm{Si}-\mathrm{O}-\mathrm{H}$. Am Mineral 59:1016-1025

Lyon WG, Westrum EF (1968) Low-temperature thermal properties of calcium tungstate. J Chem Physics 49:3374-3377

Morgan BA (1975) Mineralogy and origin of skarns in the Mount Morrison Pendant, Sierra Nevada, California. Am J Sci 275:119-142

Navrotsky A, Coons WE (1976) Thermochemistry of some pyroxenes and related compounds. Geochim Cosmochim Acta $40: 1281-1288$

Newberry RJ (1980) The geology and chemistry of skarn formation and tungsten deposition in the central Sierra Nevada, California. Unpub PhD thesis, Stanford Univ

Newberry RJ (1982) Tungsten-bearing skarns of the Sierra Nevada. I. The Pine Creek mine, California. Econ Geo1 77 :823-844

Newberry RJ (1983) The formation of subcalcic garnet in scheelitebearing skarns. Canad Mineral $21: 529-544$

Newton RC, Charlu T, Kleppa OJ (1977) Thermochemistry of high pressure garnets and clinopyroxenes of the system $\mathrm{CaO}$ $\mathrm{MgO}-\mathrm{Al}_{2} \mathrm{O}_{3}-\mathrm{SiO}_{2}$. Geochim Cosmochim Acta 41:369-377

Robie RA, Hemingway BS, Fisher JR (1978) Thermodynamic properties of minerals and related substances at $298.15 \mathrm{~K}$ and 1 bar $\left(10^{5}\right.$ pascals) pressure and at higher temperatures. US Geol Surv Bull 1452:456

Robinson GR, Haas JL, Schafer CM, Haselton HT (1983) Thermodynamic and thermophysical properties of selected phases in the $\mathrm{MgO}-\mathrm{SiO}_{2}-\mathrm{H}_{2} \mathrm{O}-\mathrm{CO}_{2}, \mathrm{CaO}-\mathrm{Al}_{2} \mathrm{O}_{3}-\mathrm{SiO}_{2}-$ $\mathrm{H}_{2} \mathrm{O}-\mathrm{CO}_{2}$, and $\mathrm{Fe}-\mathrm{FeO}-\mathrm{Fe}_{2} \mathrm{O}_{3}-\mathrm{SiO}_{2}$ chemical systems, with special emphasis on the properties of basalts and their mineral components. US Geol Surv Open File Rep 83-0079:465

Saxena SK (1973) Thermodynamics of Rock-Forming Crystalline Solutions. Springer, Berlin New York

Saxena SK (1976) Two-pyroxene geothermometer: a model with an approximate solution. Am Mineral 61:643-652

Taylor BE (1976) Origins and significance of $\mathrm{C}-\mathrm{O}-\mathrm{H}$ fluids in the formation of $\mathrm{Ca}-\mathrm{Fe}-\mathrm{Si}$ skarn, Osgood Mountains, Humboldt County, Nevada. Unpub PhD thesis, Stanford Univ

Taylor BE, Liou JG (1978) The low temperature stability of andradite in $\mathrm{C}-\mathrm{O}-\mathrm{H}$ fluids. Am Mineral 63:378-393

Wright WA (1973) Skarn-formation at Pine Creek mine, Bishop, California. Unpub PhD thesis, Univ California, Berkeley

Yakovleva RA, Rezukhina TN (1960) The heat capacity of calcium, manganese and cobalt tungstates at high temperatures. Russ J Physical Chem 34:390-392

Zharikov VA (1970) Skarns. Internat Geol Rev 12:541-559, $619-647,760-775$

Accepted January 5, 1985 